\title{
Spacing and Pruning Affect Growth, Yield, and Economic Returns of Staked Fresh-market Tomatoes
}

\author{
Jeanine M. Davis ${ }^{1}$ and Edmund A. Estes ${ }^{2}$ \\ North Carolina State University, Raleigh, NC 27695 \\ Additional index words. fruit size, Lycopersicon esculentum, shoot removal
}

\begin{abstract}
Unstable prices and increased competitive market pressures have caused many staked-tomato (Lycopersicon esculentum Mill.) producers to reexamine the costs and benefits of various production practices. In 1988 and 1989, field studies were conducted to determine if changes in plant in-row spacing and pruning could reduce production costs, increase yields, and improve grower net returns of staked 'Mountain Pride' tomatoes. In both years, early-season yields were highest using early pruning (when lateral shoots were 5 to $10 \mathrm{~cm}$ long) or delayed pruning (when lateral shoots were 30 to $36 \mathrm{~cm}$ long) and in-row spacings $\leq 46 \mathrm{~cm}$. In 1988, total-season yields per hectare of pruned plants increased as in-row spacing decreased. For nonpruned plants, however, total-season yields were high at all spacings. In 1989, total-season yields were lower from delayed-pruned plants than from nonpruned plants and there was little yield difference due to in-row spacing. In both years, nonpruned plants produced low yields of fruit $>72 \mathrm{~mm}$ in diameter but their total yields were greater than those of pruned plants. Net returns per hectare, calculated from combined data of both years, were highest when 1) plants spaced closely in-row were pruned early and 2) plants were spaced 46 to $76 \mathrm{~cm}$ apart and either pruned early or not pruned.
\end{abstract}

Staked tomato production is an important industry in the southeastern United States and the cultural system is being tested in many other parts of the country. Gross economic returns per hectare are among the highest of any vegetable crop, but production costs are also very high. Labor required for transplanting, staking, pruning, tying, and harvesting can account for up to $55 \%$ of total production costs (J.M. Davis and E.A. Estes, unpublished data). As the supply of agricultural labor decreases and production costs increase, growers must improve efficiency of cultural practices to maintain profitability.

Yield and fruit size of tomatoes are influenced by many factors, including plant spacing and pruning. In previous studies, decreasing plant population densities reduced early- (Fery and Janick, 1970; Vittum and Tapley, 1953) and total-season yields (Mohamed and Ali, 1988; Stoffella et al., 1988; Vittum and Tapley, 1953) but increased fruit size (Frost and Kretchman, 1988; Stoffella et al., 1988) and number of fruit per plant (Fery and Janick, 1970; Frost and Kretchman, 1988; Stoffella et al., 1988). Tomato cultivars with dissimilar growth habits, however, responded differently to spacing treatments (Fery and Janick, 1970; Frost and Kretchman, 1988; Stoffella et al., 1988). One of the most widely grown cultivars in the southeastern United States, 'Mountain Pride', has a large, vigorous plant habit. This vigor is controlled by pruning and limiting $\mathrm{N}$ fertilizer applications (Konsler and Gardner, 1990), but close spacing also may reduce overall vigor (Fery and Janick, 1970). Fruit quality, however, may be reduced at high plant population densities due to increased difficulty in controlling insects and diseases.

Received for publication 21 Aug. 1992. Accepted for publication 17 Mar. 1993 This research was funded in part by the North Carolina Agricultural Research Service, Raleigh. We acknowledge partial support of this study by an applied research activity grant awarded by the Tennessee Valley Authority. We also express our appreciation to George Cox for his technical assistance. Use of trade names does not imply endorsement of the products named nor criticism of similar ones not named. The cost of publishing this paper was defrayed in part by the payment of page charges. Under postal regulations, this paper therefore must be hereby marked advertisement solely to indicate this fact.

${ }^{1}$ Dept. of Horticultural Science, Mountain Horticultural Crops Research and Extension Center, 2016 Fanning Bridge Rd., Fletcher, NC 28732.

${ }^{2}$ Dept. of Agricultural and Resource Economics.
Pruning is a labor-intensive practice recommended and used on almost all staked tomatoes (Konsler and Gardner, 1990). The pruning of staked tomatoes was based on a study (unpublished data) that showed moderate pruning of 'Walter' (a determinate cultivar) increased fruit yields but that total marketable yield decreased as pruning severity increased. In addition, plants that were not pruned produced fewer large tomatoes and fewer culls than a heavily pruned plant (unpublished data). In general, pruning decreased the number of flower clusters and fruit per plant but did not affect fruit count per cluster (El Forgany and Morelock, 1982). Yield also depends on the growth stage at which defoliation occurs: defoliation of field grown tomatoes at the vegetative stage caused no yield reduction, while defoliation during the reproductive stage reduced yields in proportion to the level of defoliation (Wolk et al., 1983). The objective of this study was to determine if changes in spacing and pruning of staked 'Mountain Pride' tomatoes could reduce production costs, increase yields, and improve grower profits.

\section{Materials and Methods}

Field studies in 1988 and 1989 were conducted on Delanco loam (fine loamy, mixed, mesic, Aquic Hapludults) in Fletcher, N.C. The design for both years was a randomized complete block and factorial of spacing $\times$ pruning with four replications. Pruning treatments consisted of a) no pruning; b) early pruning, when lateral shoots were 5 to $10 \mathrm{~cm}$ long; and c) delayed pruning, when the lateral shoots were 30 to $36 \mathrm{~cm}$ long. For both pruning treatments, lateral shoots were removed from the base of the plant up to, but not including, the shoot immediately below the first flower cluster. In 1988, in-row spacing treatments were 31,46,61, 76 , and $91 \mathrm{~cm}$. In 1989, these same five spacings plus 15 and 107 $\mathrm{cm}$ were used.

Plots consisted of three 4.6-m-long rows spaced $1.5 \mathrm{~m}$ apart. Yield data were collected from the center rows; the outer rows served as guard rows. Limestone, $\mathrm{P}, \mathrm{K}$, and $84.1 \mathrm{~kg} \mathrm{~N} / \mathrm{ha}$, based on soil test results (North Carolina Dept. of Agriculture, 1987), were broadcast-applied and incorporated. Beds were shaped and fumigated with a mixture of $67 \%$ methyl bromide and $33 \%$ chloropicrin $\left.\left(\mathrm{CCl}_{3} \mathrm{NO}_{2}\right)\right)$ at $224 \mathrm{~kg} \cdot \mathrm{ha}^{-1} 1$ month before planting. At the same 
time, black polyethylene mulch $(1.5 \mathrm{~m}$ wide $\times 0.04 \mathrm{~mm}$ thick $)$ and drip irrigation tape (30.5-cm emitter spacing) (Ro-Drip; Roberts Irrigation Products, San Marcos, Calif.) were applied. The drip tape was placed $4 \mathrm{~cm}$ deep and $10 \mathrm{~cm}$ from the center of the bed. Five-week-old greenhouse-grown 'Mountain Pride' transplants were set out on 8 June 1988 and 14 June 1989. Recommended weed, disease, and insect controls were used (North Carolina State Univ., 1988). In 1988, beginning 6 weeks after planting, additional $\mathrm{N}$ and $\mathrm{K}$ were applied weekly through the irrigation system at 48 $\mathrm{kg} \mathrm{KNO}_{3}$ and $27 \mathrm{~kg} \mathrm{Ca}\left(\mathrm{NO}_{3}\right)_{2}$ per hectare. In 1989, 20N-8.6P$16.6 \mathrm{~K}$ fertilizer was applied weekly at $28 \mathrm{~kg} \cdot \mathrm{ha}^{-1}$ through the irrigation system beginning 4 weeks after planting.

Fruit exhibiting any pink were harvested weekly, beginning 17 Aug., for 7 weeks in 1988 and 8 weeks in 1989. In both years, early-season yields included the first 2 weeks of harvest (17-24 Aug.) and mid-season yields included the third through fifth weeks of harvest (31 Aug.-14 Sept.). Late-season yields included the sixth and seventh weeks of harvest (21-28 Sept.) in 1988, and sixth through eighth weeks of harvest (21 Sept.-5 Oct.) in 1989. Fruit were graded into U.S. Combination, U.S. no. 3, and culls (North Carolina Dept. of Agriculture, 1986). U.S. Combination fruit were graded according to diameter into jumbo (>88 mm), extra large (73 to $88 \mathrm{~mm})$, large (64 to $72 \mathrm{~mm}$ ), and medium ( 58 to $63 \mathrm{~mm})$. All yields reported were marketable fruit (U.S. Combination and U.S. no. 3) per hectare. Plants were harvested and weighed after the final harvest.

Preharvest production costs, including all materials and labor, were calculated for each treatment. Labor costs were based on the average rate paid for hired laborers in North Carolina $(\$ 5.50 / \mathrm{h})$. Total production costs included preharvest costs plus costs of harvesting and packing. Harvesting and packing costs were set at $\$ 3.25$ per $9.07-\mathrm{kg}$ box. Net returns were calculated by subtracting total production costs from gross returns. Gross returns were calculated using the daily prices for fresh-market, staked tomatoes (loaded on the truck, but not shipped) at western North Carolina shipping points.

All data were subjected to analysis of variance (SAS Institute, Cary, N.C. or MSTAT, Michigan State Univ.) and, where appropriate, to linear and quadratic regression analyses or simple correlation (MSTAT).

\section{Results and Discussion}

Yields. Yields in both years were influenced by spacing and pruning (Table 1). In 1988, highest early-season yields (first two harvests) were obtained with pruning, early and delayed, at the closest in-row spacings-31 and $46 \mathrm{~cm}$ (Fig. 1A). For all pruned plants, early-season yields decreased as in-row spacing increased. In contrast, early-season yields of nonpruned plants were low and did not respond to spacing. A correlation of high early-season yields with high plant populations has been reported for many tomato cultivars under a wide range of conditions (Fery and Janick, 1970; Odland, 1949; Vittum and Tapley, 1953; West and Peirce, 1988). Fery and Janick (1970) concluded that, as plant populations increase, intraplant competition becomes more important and eventually only flowers on the earliest clusters set fruit. Thus, early yields increased as plant populations increased because there were more early clusters per unit area. In these other studies, however, there was no indication that plants were pruned (Fery and Janick, 1970; Odland, 1949; Vittum and Tapley, 1953; West and Peirce, 1988). It seems that nonpruned plants continued to partition carbohydrates to vegetative growth, instead of reproductive growth, longer than pruned plants.
By mid-season, nonpruned plants produced yields as high or higher than plants in the other two pruning treatments at all spacings (Fig. 1B). In sharp contrast to yields of nonpruned plants, yields of pruned plants decreased as spacing between plants increased. By late season, there was no response to spacing by any treatment and, in general, yields from nonpruned plants were lower than those from pruned plants (Fig. 1C).

Generally, total-season yields increase as plant populations increase to an optimum level (Fery and Janick, 1970; Stoffella et al., 1988; Vittum and Tapley, 1953; West and Peirce, 1988). In this study, however, only pruned plants exhibited this response to closer spacing (Fig. 2A), a result suggesting that source strength limited yields (Fisher, 1975). In nonpruned plants, total-season yields were high at all spacings. There were no yield differences at any spacing between the early and delayed pruning treatments.

As in 1988, early-season yield in 1989 was highest at the closest spacing and decreased as in-row spacing increased (Fig. 1D). Early-season yield in 1989 was much lower than in 1988, probably because the cloudy weather and heavy rains during June 1989 (300 $\mathrm{mm}$ in 1989 compared to $20 \mathrm{~mm}$ in 1988) reduced fruit set. As in 1988, during mid-season, nonpruned plants yielded as high or

Table 1. Significance of reproductive and vegetative responses of staked tomato to spacing and pruning.

\begin{tabular}{|c|c|c|c|}
\hline \multirow{2}{*}{$\begin{array}{l}\text { Variable } \\
\text { and year }\end{array}$} & \multicolumn{2}{|c|}{ Treatment } & \multirow{2}{*}{$\begin{array}{l}\text { Interaction } \\
\qquad \mathbf{S} \times \mathbf{P}\end{array}$} \\
\hline & Spacing (S) & Pruning $(\mathrm{P})$ & \\
\hline \multicolumn{4}{|c|}{ Marketable fruit yield, season } \\
\hline \multicolumn{4}{|l|}{1988} \\
\hline Early & $* *$ & $* *$ & * \\
\hline Middle & NS & $* *$ & $* *$ \\
\hline Late & NS & $*$ & NS \\
\hline Total & $* *$ & ** & ** \\
\hline \multicolumn{4}{|l|}{1989} \\
\hline Early & $* *$ & $* *$ & $* *$ \\
\hline Middle & $*$ & ** & NS \\
\hline Late & $* *$ & $*$ & NS \\
\hline Total & NS & ** & NS \\
\hline \multicolumn{4}{|l|}{ Fruit size } \\
\hline \multicolumn{4}{|l|}{1988} \\
\hline Large & ** & ** & * \\
\hline Extra large + jumbo & NS & $* *$ & $* *$ \\
\hline \multicolumn{4}{|l|}{1989} \\
\hline Large & $* *$ & $* *$ & NS \\
\hline Extra large + jumbo & $* *$ & $* *$ & NS \\
\hline \multicolumn{4}{|c|}{ Average fruit weight, season } \\
\hline \multicolumn{4}{|l|}{1988} \\
\hline Early & $* *$ & $* *$ & NS \\
\hline Middle & $* *$ & $* *$ & NS \\
\hline Late & NS & $* *$ & NS \\
\hline \multicolumn{4}{|l|}{1989} \\
\hline Early & * & NS & NS \\
\hline Middle & $* *$ & $* *$ & NS \\
\hline Late & $* *$ & $* *$ & NS \\
\hline \multicolumn{4}{|l|}{ Plant weight } \\
\hline \multicolumn{4}{|l|}{1988} \\
\hline Per plant & $* *$ & $* *$ & $* *$ \\
\hline Per plot & $* *$ & $* *$ & NS \\
\hline \multicolumn{4}{|l|}{1989} \\
\hline Per plant & $* *$ & ** & NS \\
\hline Per plot & $* *$ & $* *$ & NS \\
\hline
\end{tabular}




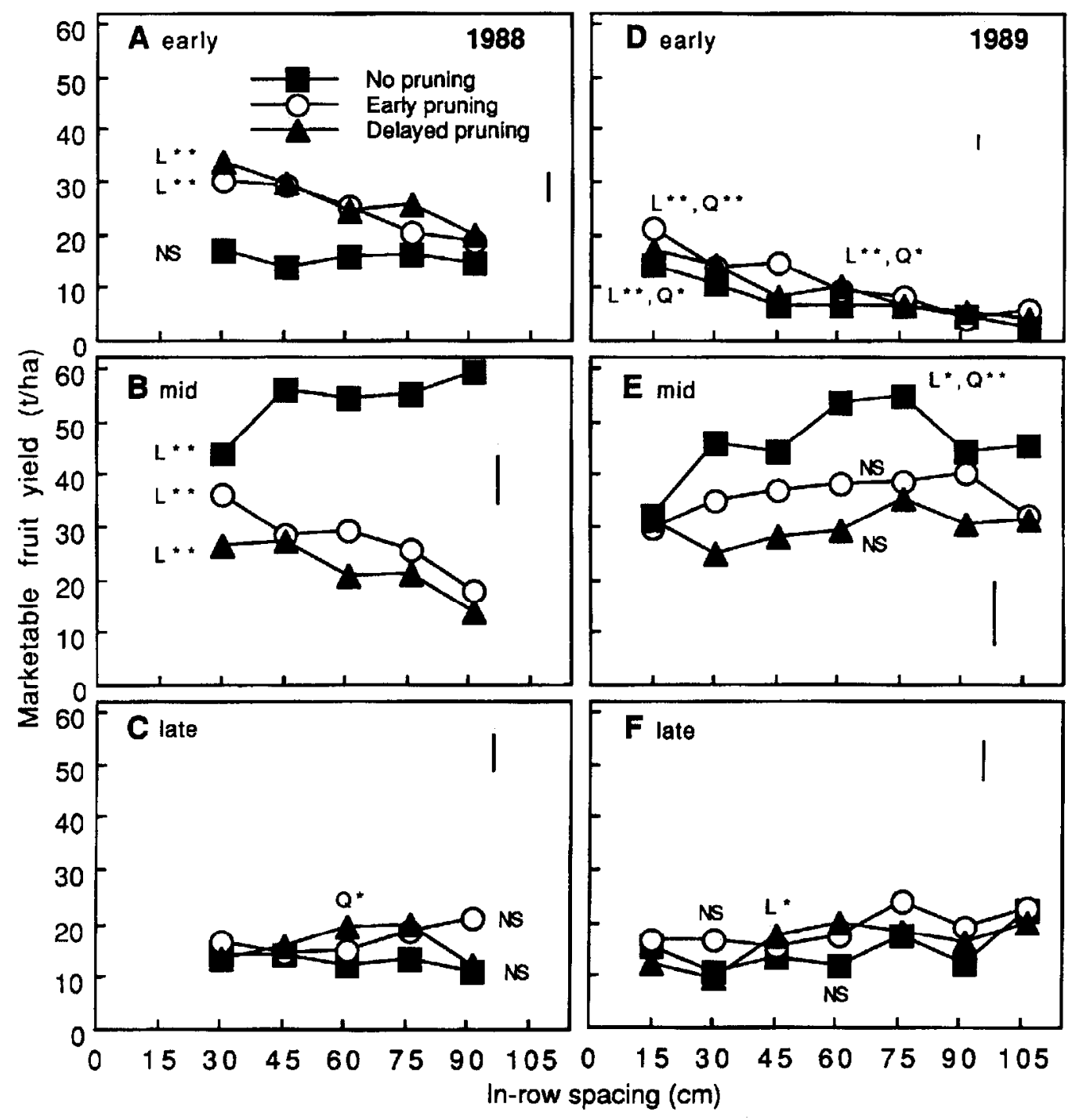

Fig. 1. Influence of spacing and pruning on early, mid- and late-season yields of tomatoes in 1988 (A-C) and 1989 (D-F).

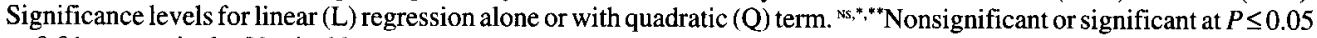
or 0.01 , respectively. Vertical bars represent $\mathrm{LSD}_{0.05}$.

higher than pruned plants, although in 1989 pruned plants did not respond to spacing (Fig. 1E). By late season, as in 1988, nonpruned plants generally produced the lowest yields (Fig. 1F).

In 1989, unlike 1988, total-season yield did not respond to spacing (Fig. 2B). Although during the early season the highest yield was obtained with close spacings, during mid-season the highest overall yield was obtained with the mid-range spacings and, during the late season, the highest overall yield was obtained at the widest spacings, a result that effectively nullifies any differences due to plant spacing over the total season (Fig. 1D-F). Overall, delayed pruning produced the lowest total-season yields (Fig. 2B).

Fruit weight and size. In both years, pruning and spacing affected average fruit weight in most seasons (Table 1). In general, nonpruned plants-produced fruit of lower weight, particularly during mid-season (Fig. 3). As reported previously (Fery and Janick, 1970; Frost and Kretchman, 1988; Mohamed and Ali, 1988; Stoffella et al., 1988), fruit weight generally increased as plant population densities decreased. Closely spaced plants that were not pruned always produced small fruit.

Average fruit weight, however, is of little importance to a grower. Production economics are determined by the number of fruit in large size categories because of the big price differences based on size. In both years, nonpruned plants produced many large (64 to $72 \mathrm{~mm}$ in diameter) fruit, regardless of plant spacing (Fig. 4A and C). For pruned plants, however, yields of large fruit decreased as in-row spacing increased. Yields of extra large and jumbo (>73 $\mathrm{mm}$ in diameter) fruit from nonpruned plants increased with increasing in-row spacing in both years (Fig. 4B and D). In 1988, extra large and jumbo fruit yields from pruned plants decreased as plant population density decreased. In 1989, however, delayed-pruned plants did not respond to spacing, and early-pruned plants had only a slightly higher yield of extra large and jumbo fruit with wide spacing.

We assumed that treatments that produced the largest average fruit weights during the harvest season would have the highest total yields in the largest size categories. This assumption was not always correct. In all three harvest seasons of 1989, average fruit weight was high with early-pruned plants spaced $75 \mathrm{~cm}$ apart (Fig. 3D-F). As expected, highest total yields of extra large and jumbo fruit were obtained with early-pruned plants spaced $75 \mathrm{~cm}$ apart (Fig. 4D). In 1988, however, highest total yields of extra large and jumbo fruit came from early-pruned plants at the closes; spacing (Fig. 4B), but this treatment did not provide a high average fruit 


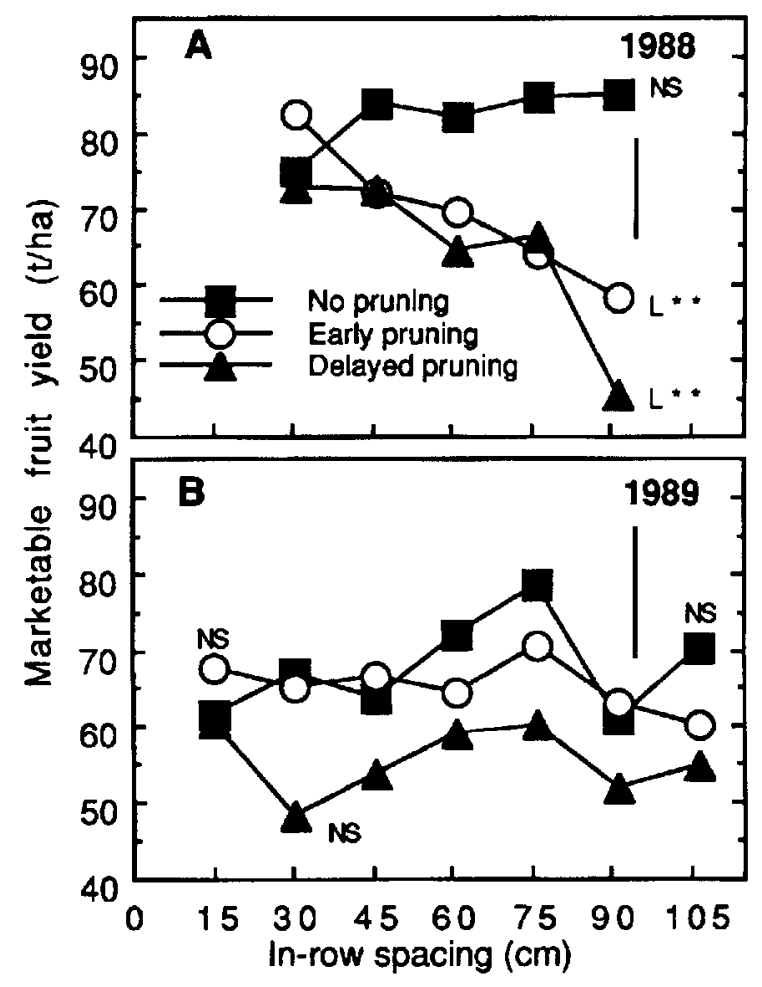

Fig. 2. Influence of spacing and pruning on total-season yields of tomatoes in 1988 (A) and 1989 (B). Significance levels for linear (L) regression alone or with

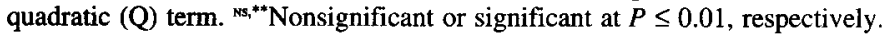
Vertical bars represent $L_{S D_{0.05}}$. weight in any harvest season (Fig. 3A-C).

Plant growth. In studies on a variety of staked and ground-cultured tomatoes, plant size increased as in-row spacing increased, a result indicating that competition between plants limited plant size (Fery and Janick, 1970; Frost and Kretchman, 1988; Stoffella et al., 1988). In 1989, this same response was observed in all three pruning treatments (Fig. 5B). In 1988, nonpruned plants also exhibited a positive linear response to increased spacing; but, in pruned plants, the response was quadratic, a result suggesting that pruning limited plant growth (Fig. 5A). In general, plants were smallerin 1989 than in 1988, probably as a result of the $300 \mathrm{~mm}$ of rain and low light intensities during the first 4 weeks after transplanting. In 1989, the delayed-pruning treatment resulted in smaller plants than the nonpruned or early-pruning treatments (Fig. 5B). Since plants with delayed pruning also produced the lowest yields, the small plant size (low source strength) may have limited yield (Fisher, 1975). The largest plants with the least competition for light, water, and nutrients (nonpruned plants at wide spacing) produced the highest yield.

When expressed on a per unit land area basis, plant weight decreased as in-row spacing increased in 1988 (Fig. 5C). The response was similar to that of total yield (Fig. 2A), and the correlation between the two (fruit weight per square meter vs. plant weight per square meter) was high $(r=0.7)$. In 1989 , the response patterns of plant biomass to spacing and pruning (Fig. 5D) were similar to those of yield (Fig. 2B). There was not, however, a correlation between plant biomass and fruit weight in 1989 ( $r=$ $0.2)$.

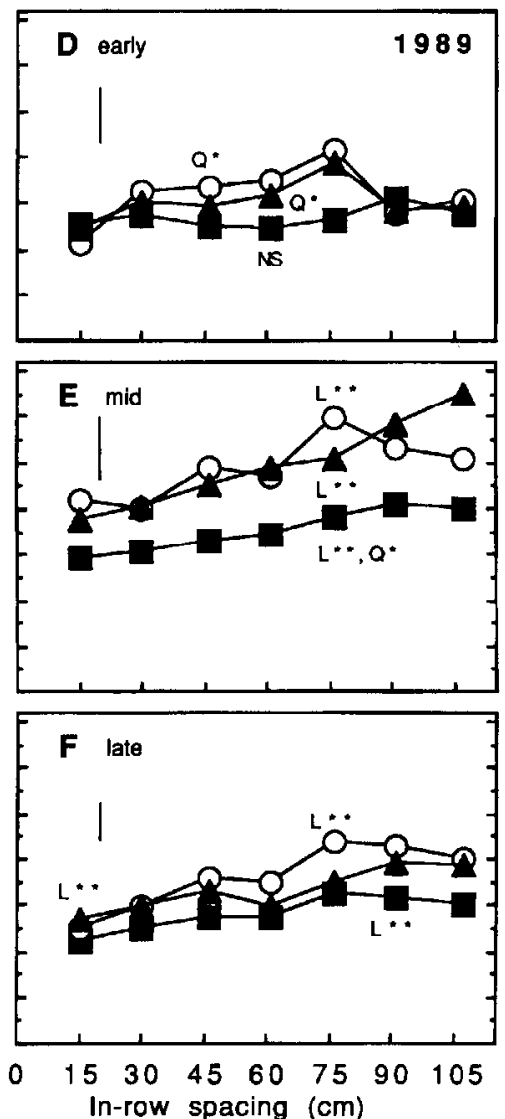

Fig. 3. Influence of spacing and pruning on (A and $\mathbf{D})$ early-, $(\mathbf{B}$ and $\mathbf{E})$ mid- and $(\mathbf{C}$ and $\mathbf{F})$ late-season average tomato size in 1988 and 1989. Significance levels for linear (L) regression alone or with quadratic $(\mathrm{Q})$ term. ${ }^{\mathrm{Ns}, * * *}$ Nonsignificant or significant at $P \leq 0.05$ or 0.01 , respectively. Vertical bars represent $\mathrm{LSD}_{0.05}$. 


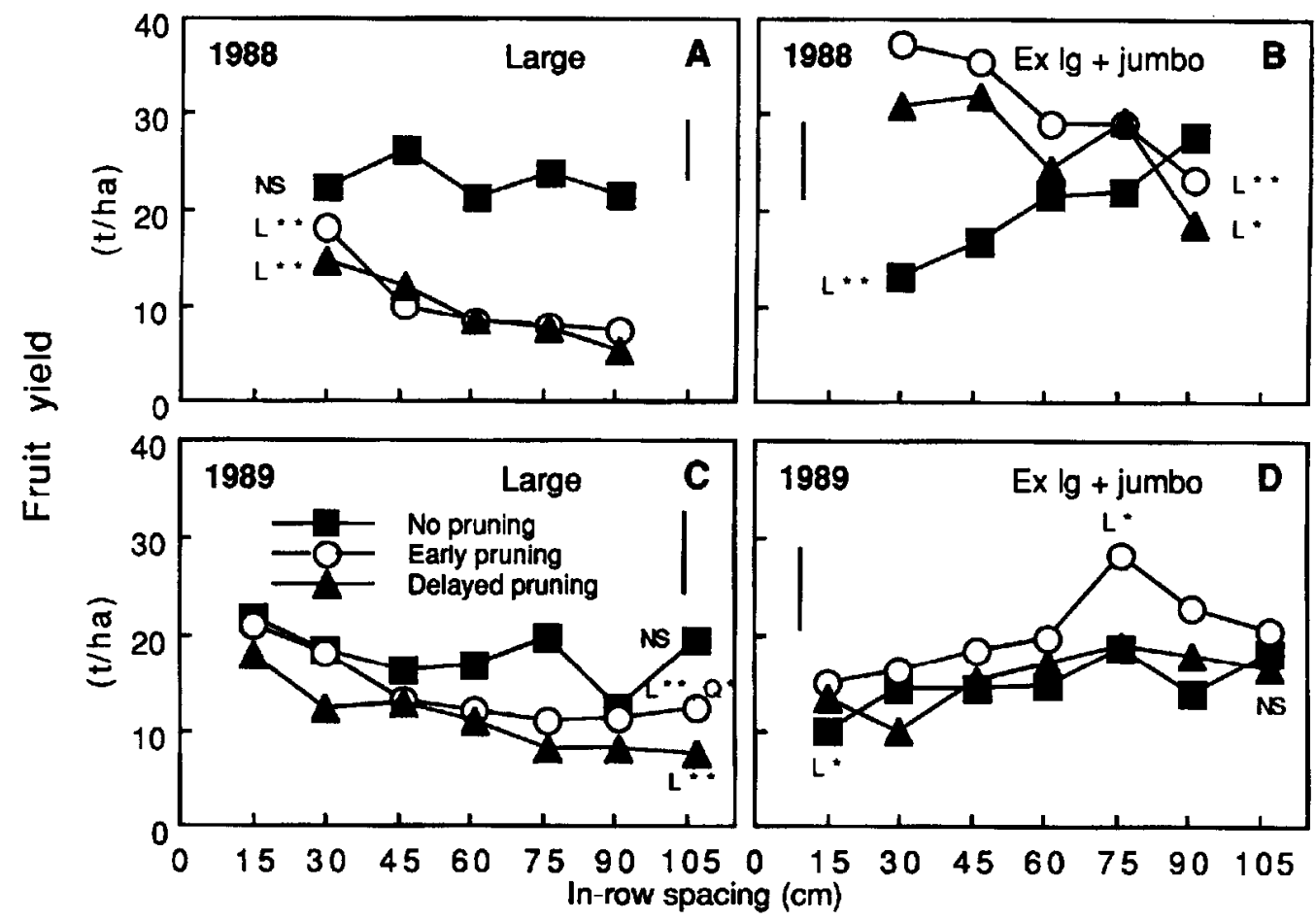

Fig. 4. Influence of spacing and pruning on yields of large (64 to $73 \mathrm{~mm}$ in diameter) (A and $\mathbf{C}$ ) and extra large + jumbo (>73 mm in diameter) (B and D) tomatoes in 1988 and 1989. Significance levels for linear (L) regression alone or with

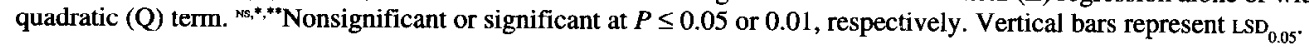
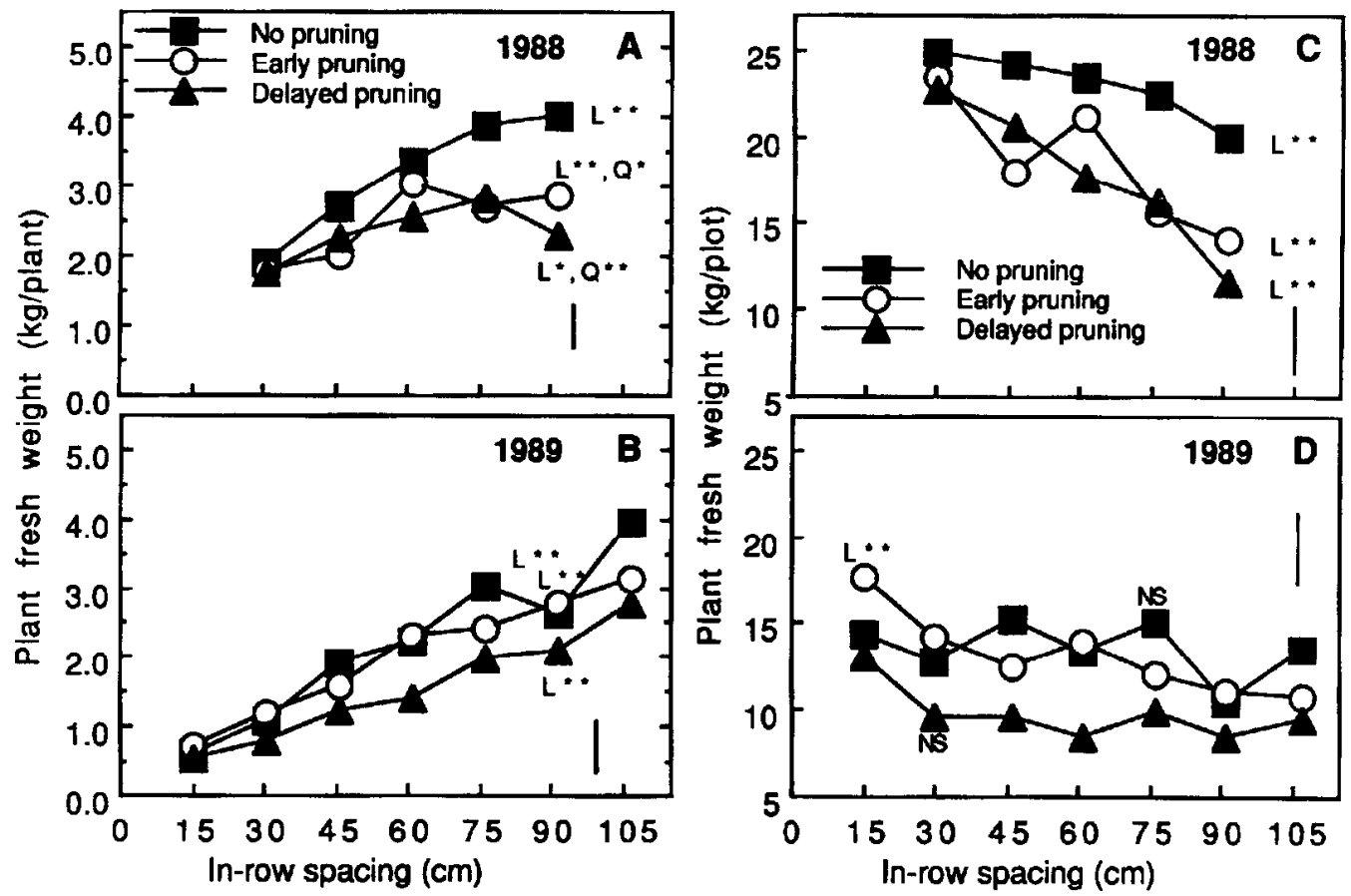

Fig. 5. Influence of spacing and pruning on per plant fresh weight ( $\mathbf{A}$ and $\mathbf{B})$ and total plant fresh weight ( $\mathbf{C}$ and $\mathbf{D})$ per plot in 1988 and 1989. Significance levels for linear (L) regression alone or with quadratic (Q) term. "s,",**Nonsignificant, or significant at $P \leq 0.05$ or 0.01 , respectively. Vertical bars represent $\mathrm{LSD}_{0.05}$.

Production costs. Changes in spacing and pruning had a large effect on production costs (Table 2). In both years, preharvest production costs decreased as in-row spacing increased, and nonpruned plants were less expensive to produce than pruned plants (Fig. 6A). This was a result of differences in transplant costs and labor costs to plant and prune. Total production costs in 1988, however, were highest for nonpruned plants because they pro- duced the greatest yields (Fig. 2A), and thus had the highest harvest and packing costs (Fig. 6B). In 1989, total production costs also correlated highly with yields such that the treatments producing highest yields (Fig. 2B) had the highest total production costs (Fig. 6C).

Net returns. Net returns were affected by pruning but not by in-row spacing (Table 2). In 1988, highest net returns were 
Table 2. Significance of economic responses of staked tomato to spacing and pruning.

\begin{tabular}{lccc}
\hline \hline & \multicolumn{2}{c}{ Treatment } & Interaction \\
\cline { 2 - 3 } Parameter & Spacing (S) & Pruning (P) & S $\times \mathrm{P}$ \\
\hline $\begin{array}{l}\text { Preharvest costs } \\
\quad \text { 1988-89 }\end{array}$ & $* *$ & $* *$ & $* *$ \\
Total production costs & $* *$ & $* *$ & $* *$ \\
1988 & NS & $* *$ & NS \\
1989 & & & \\
Net returns & NS & $*$ & $* *$ \\
1988 & NS & $*$ & NS \\
1989 & & & \\
Combined net returns & NS & $*$ & NS \\
$1988-89$ & NS & & \\
\hline
\end{tabular}

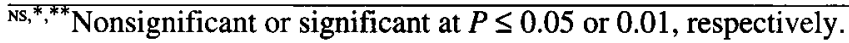

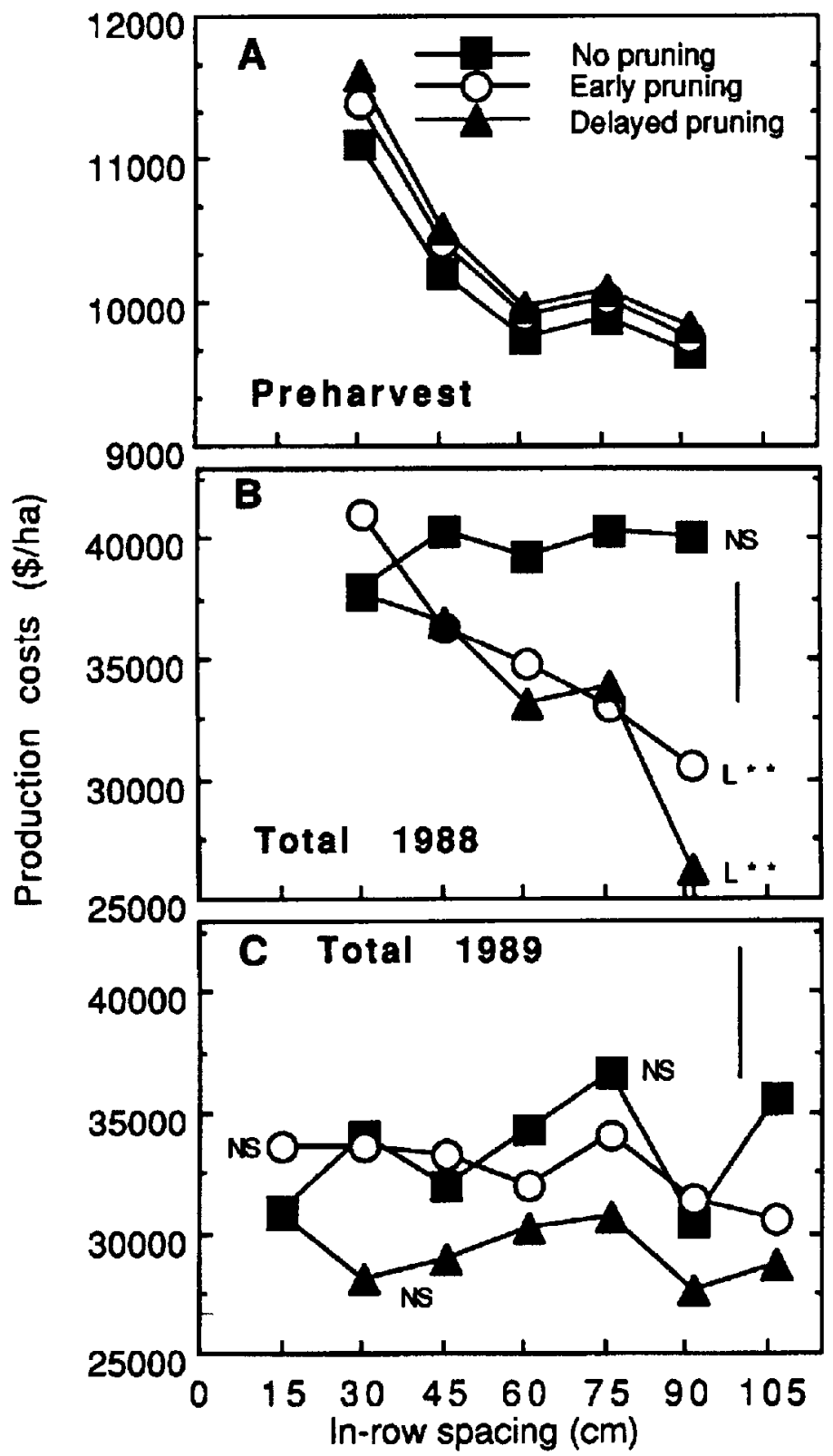

Fig. 6. Influence of spacing and pruning of staked tomato on preharvest production costs (A) and total production costs in 1988 (B) and 1989(C). Significance levels for linear $(\mathrm{L})$ regression alone or with quadratic $(\mathrm{Q})$ term. "ss,"Nonsignificant or significant at $P \leq 0.01$, respectively. Vertical bars represent $\mathrm{LSD}_{0.05}$. obtained with 1) $31 \mathrm{~cm}$ spacing and early pruning and 2) $91 \mathrm{~cm}$ spacing without pruning (Fig. 7A). In 1989, net returns were highest with 1) $15 \mathrm{~cm}$ spacing and early pruning and 2) $76 \mathrm{~cm}$ spacing with no pruning or early pruning (Fig. 7B). Delayed pruning reduced net returns at most plant spacings.

For high net returns, harvest time was critical. In both years, close spacing with pruning produced high yields when early market prices were high. When plants were spaced farther apart or not pruned, harvest was delayed but overall yields were higher. The higher yield later in the season compensated for lower market prices so that net returns were similar.

Fruit size also had a large effect on net returns. In 1989, the difference in price of a $11.3-\mathrm{kg}$ box of jumbo or extra large tomatoes compared to large tomatoes was $\$ 1.25$ to $\$ 1.50$. In 1988 , the difference was about $\$ 2.20 /$ box.
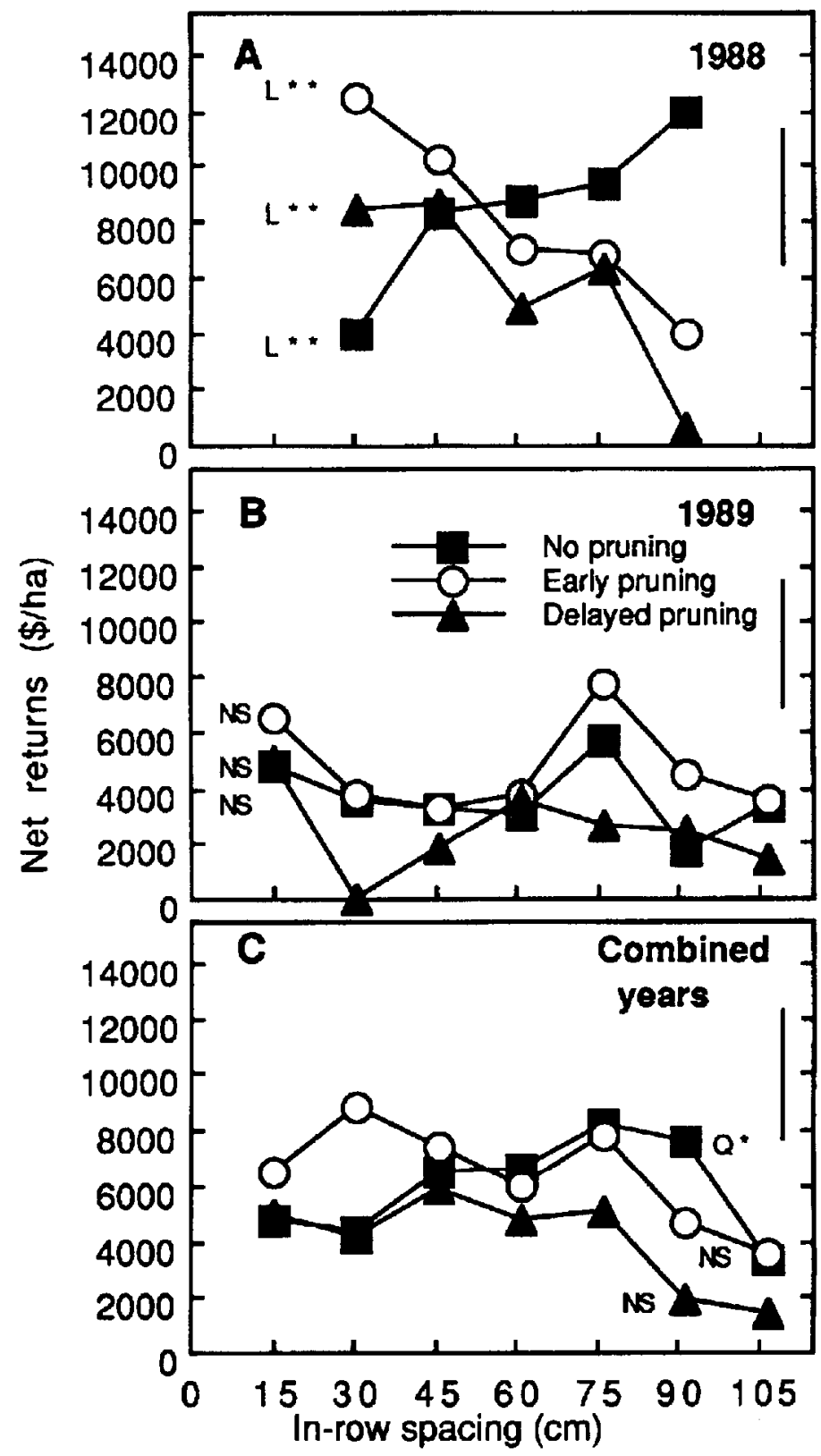

Fig. 7. Influence of spacing and pruning of staked tomato on net returns in 1988 (A) and 1989 (B) and on combined 1988 and 1989 returns (C). Significance levels for linear $(\mathrm{L})$ regression alone or with quadratic $(\mathrm{Q})$ term. ${ }^{\mathrm{N}, * * *}$, Nonsignificant or significant at $P \leq 0.05$ or 0.01 , respectively. Vertical bars represent $\mathrm{LSD}_{0.05}$. 
The combined data for both years indicated that the highest returns were obtained with 1) close in-row spacings and early pruning and 2) 46 to $76 \mathrm{~cm}$ in-row spacing and no pruning or early pruning (Fig. 7C).

\section{Conclusion}

Production costs, time of harvest, total yields, fruit weight, and fruit size can be manipulated by in-row plant spacing and pruning practices. High net returns can be obtained by producing 1) high early-season yields when prices are high, 2) large volumes of jumbo and extra large fruit for the premium prices they bring, or 3) high total yields with reduced production costs (not including harvesting and packing).

If high early-season yields are desired, plants should be spaced closely (146 cm) and pruned early. If labor supply is deficient and pruning is eliminated, plants should be spaced $\geq 76 \mathrm{~cm}$ apart in the row to give high total yields of smaller fruit. To produce a large volume of jumbo and extra large fruit, plants should be pruned early and spaced $\geq 46 \mathrm{~cm}$ in the row.

If pruning is delayed so that lateral shoots are longer than $10 \mathrm{~cm}$, pruning becomes more difficult and, therefore, more time consuming and costly. Total season yields may be reduced by delayed pruning compared to not pruning.

\section{Literature Cited}

El Forgany, M.M. and T.E. Morelock. 1982. Effect of pruning intensity and soil moisture levels on tomato fruit cracking. HortScience 17:86. (Abstr.)
Fery, R.L. and J. Janick. 1970. Response of the tomato to population pressure. J. Amer. Soc. Hort. Sci. 95:614-624.

Fisher, K.J. 1975. Effect of the amount and position of leaf tissue on the yield of single-truss tomatoes. Scientia Hort. 3:303-308.

Frost, D.J. and D.W. Kretchman. 1988. Plant spatial arrangement and density effects on small- and medium-vined processing tomatoes. J. Amer. Soc. Hort. Sci. 113:51-55.

Konsler, T.R. and R.G. Gardner. 1990. Commercial production of staked tomatoes in North Carolina. Agr. Ext. Serv. North Carolina State Univ. Publ. AG-405.

Mohamed, S.F. and Z.E. Ali. 1988. Effect of in-row spacing and levels of nitrogen fertilizer on the yield and quality of direct-seeded tomatoes. Acta Hort. 218:207-212.

North Carolina Department of Agriculture. 1986. Tomato grade booklet. North Carolina Dept. of Agr.

North Carolina Department of Agriculture. 1987. Crop fertilization based on N.C. soil tests. North Carolina Dept. of Agr. Circ. 1.

North Carolina State University. 1988. Agricultural chemicals manual. North Carolina State Univ.

Odland, M.L. 1949. Interrelation of spacing, variety and interplanting on yield and fruit size of tomatoes. Proc. Amer. Soc. Hort. Sci. 53:393-401.

Stoffella, P.J., S.J. Locascio, P.H. Everett, T.K. Howe, J.W. Scott, and S.M. Olson. 1988. Yields of two tomato cultivars differing in shoot growth at several plant populations and locations. HortScience 23:991993.

Vittum, M.T. and W.T. Tapley. 1953. Spacing and fertility level studies with a determinate-type tomato. Proc. Amer. Soc. Hort. Sci. 61:339342.

West, J. and L.C. Peirce. 1988. Yields of tomato phenotypes modified by planting density, mulch and row covers. HortScience 23:321-324.

Wolk, J.O., D.W. Kretchman, and D.G. Ortega. 1983. Response of tomato to defoliation. J. Amer. Soc. Hort. Sci. 108:536-540. 